\title{
Eigen koers richting kalifaat, een beeld van Hizb ut-Tahrir in Nederland ${ }^{*}$
}

\author{
Peter Grol \& Daan Weggemans
}

\section{Inleiding}

Voor de problemen die moslims in deze wereld ervaren is volgens Hizb ut-Tahrir maar één oplossing: een kalifaat. De term 'kalifaat' is sinds de opkomst van jihadistische organisaties zoals Al Qaida en ISIS onlosmakelijk verbonden met de meedogenloze strijd die deze terroristische organisaties voeren en die vele duizenden mensen het leven kostten. Het is dan ook niet verwonderlijk dat tijdens een Tweede Kamerdebat over de aanpak van Nederlandse jihadstrijders in 2014 Van Hearsma Buma (CDA) de regering opriep om Hizb ut-Tahrir te verbieden. Hij omschreef deze als een organisatie die de democratie en rechtsstaat omver wil werpen en de sharia wil invoeren. ${ }^{1}$ Een dergelijke oproep tot een verbod op Hizb ut-Tahrir is niet nieuw. De beweging is al jaren het middelpunt van een discussie die draait om de vraag hoe er in Nederland moet worden omgegaan met antidemocratische partijen. Een repressieve aanpak van de beweging staat al bijna twee decennia op de politieke agenda van verschillende landelijke partijen. ${ }^{2}$

Hizb ut-Tahrir is wereldwijd actief in tientallen landen. Maar wat wil deze beweging nu precies in Nederland? Waar wil deze politieke beweging het beoogde kalifaat precies vestigen en wat doen aanhangers in Nederland om dat doel te bereiken? Daarover is nog maar weinig bekend. Het is belangrijk om deze vragen nauwkeurig te beantwoorden om nader in te kunnen gaan op de vraag hoe Hizb ut-Tahrir zich verhoudt tot de Nederlandse samenleving - een vraag die centraal zal staan in een volgend artikel. In het onderhavige artikel zullen eerst het gedachtegoed en de praktijk van Hizb ut-Tahrir in Nederland worden beschreven. Hizb ut-Tahrir ('Partij van de Vrijheid') heeft iets ongrijpbaars. Het is een beweging die zichzelf 'partij' noemt, met een partijprogramma en een breed scala aan publicaties op haar website. ${ }^{3}$ Maar de beweging is niet geïnstitutionaliseerd. Er bestaat in Nederland geen stichting of vereniging met deze naam en de beweging is terughoudend in het delen van informatie over bijvoorbeeld organisatiestructuur, het lidmaatschap en het leiderschap. Die terughoudendheid en organisatievorm komt onder andere voort uit de slechte verhouding tussen Hizb ut-Tahrir en overheden wereldwijd. Sinds de oprichting van de beweging in 1953 worden (vermeende) aanhangers vervolgd en beschuldigd van betrokkenheid bij terroris-

* Dit artikel is geschreven op persoonlijke titel.

1 Kamerstukken II 2013/14, 29754, nr. 105. Beschikbaar op https://zoek.officielebekend makingen.nl/h-tk-20132014-105-6.html.

2 Zie bijv. Kamerstukken II 2003/04, 27925, nr. 108, p. 1-2. Zie ook Kamerstukken II 2005/06, 29754, nr. 54, p. 20.

3 http://hizb-ut-tahrir.nl/index.php/boeken. 
tische activiteiten en het voorbereiden van couppogingen. ${ }^{4}$ De beweging is in de meeste Arabische landen verboden, evenals in bijvoorbeeld Duitsland (sinds 2003) en Indonesië (sinds 2017). Als reactie op een reeks jihadistische aanslagen in Londen op 7 juli 2005 kondigde de Britse regering aan Hizb ut-Tahrir te zullen verbieden, maar van een verbod is het tot op heden niet gekomen. ${ }^{5}$ In Nederland duikt de naam Hizb ut-Tahrir vanaf eind jaren negentig op in publieke rapportages van de Binnenlandse Veiligheidsdienst (BVD, later hernoemd tot de Algemene Inlichtingen- en Veiligheidsdienst (AIVD)), en de Nationaal Coördinator Terrorismebestrijding en Veiligheid (NCTV). ${ }^{6}$

Hierna zal eerst een beeld geschetst worden van de activiteiten en ideeën van Hizb ut-Tahrir in Nederland. Dit beeld is gebaseerd op inzichten die zijn verkregen uit literatuur over Hizb ut-Tahrir, nieuwsberichten, geschreven publicaties van Hizb ut-Tahrir en andersoortig bronmateriaal, zoals video's en online publicaties. Dit beeld is natuurlijk niet alomvattend of statisch, maar eerder een beeld van de organisatie zoals wij die als onderzoekers - relatieve buitenstaanders - door de jaren heen hebben leren kennen. Politieke bewegingen zijn veranderlijk als de mens zelf. Het hierna gepresenteerde beeld is bedoeld om een bijdrage te leveren aan de discussie over Hizb ut-Tahrir in de Nederlandse context, die continu in ontwikkeling is.

Naast de genoemde documentatie is het navolgende beeld ook gebaseerd op inzichten die verkregen zijn door de eerste auteur tijdens bezoeken aan conferenties en andere publieke bijeenkomsten van Hizb ut-Tahrir, zoals demonstraties en lezingen in de periode 2009-2017. Tijdens dit soort bijeenkomsten is het mogelijk geweest om korte gesprekken te voeren met aanhangers van Hizb ut-Tahrir die de organisatie publiekelijk vertegenwoordigen. Ook konden korte gesprekken worden gevoerd met personen die deze bijeenkomsten bezochten omdat ze interesse hadden in de ideeën van Hizb ut-Tahrir; deze groep mensen duiden wij hierna aan als 'geïnteresseerden'. Dit soort interacties hielp bij het beter doorgronden van de aard van de ideeën en de activiteiten van de organisatie.

4 Zie bijv. S. Taji-Farouki, A Fundamental Quest, Hizb al-Tahrir and the Search of the Islamic Caliphate, Londen: Grey Seal 1996, p.7. Zie ook 'Pakistan army officer held over suspected Hizb utTahrir links', The Guardian 21 juni 2011, beschikbaar op www.theguardian.com/world/2011/jun/ 21/pakistan-army-officer-hizb-ut-tahrir; 'Until the very end, Politically motivated Imprisonment in Uzbekistan', Human Rights Watch 25 september 2014, beschikbaar op www.hrw.org/report/ 2014/09/25/until-very-end/politically-motivated-imprisonment-uzbekistan; 'Six suspected Hizb ut-Tahrir members detained in Crimea', TASS 7 juli 2020, beschikbaar op https://tass.com/ emergencies/1175565.

5 Zie bijv. 'Full text: The prime minister's statement on anti-terror measures', The Guardian 5 augustus 2005, beschikbaar op www.theguardian.com/politics/2005/aug/05/uksecurity. terrorism1. Zie ook 'Watchdog recommends Tory U-turn on banning Hizb ut-Tahrir', The Guardian 18 juli 2011, beschikbaar op www.theguardian.com/politics/2011/jul/18/watchdog-toryuturn-hizb-ut-tahrir-ban.

6 Zie bijv. Binnenlandse Veiligheidsdienst, De politieke Islam in Nederland, 1998, p. 20, 22. Zie ook Jaarverslagen AIVD 2003, 2005, 2007, 2009, 2010, 2011, beschikbaar op www.aivd.nl/ onderwerpen/jaarverslagen; Dreigingsbeeld Terrorisme Nederland 16, 33, 28, 42, NCTV, beschikbaar op www.nctv.nl/onderwerpen/dtn/documenten. 


\section{Activiteiten van Hizb ut-Tahrir in Nederland}

Eind jaren negentig rapporteerde de BVD voor het eerst over Hizb ut-Tahrir in Nederland. De BVD stelt vast dat 'verspreid over Nederland kleine groepjes met enkele tientallen leden het gedachtengoed van de HUT [Hizb ut-Tahrir; auteurs] aanhangen'. Deze aanhangers richten zich volgens de BVD bij het verspreiden van hun boodschap vooral op Turken in Nederland. ${ }^{7}$ Het precieze aantal aanhangers van de beweging in Nederland is anno 2020 niet openbaar bekend, maar in de afgelopen vijf jaar zijn enkele tientallen Nederlandstalige aanhangers publiekelijk naar voren getreden, bijvoorbeeld in online video's van Hizb ut-Tahrir en andere publieke activiteiten. Zo geven zij bijvoorbeeld lezingen, toespraken of verklaringen namens Hizb ut-Tahrir. Deze groep aanhangers met uiteenlopende etnische achtergronden lijkt vanaf 2010 langzaam gegroeid te zijn, mede omdat het verloop in de groep laag is, waaruit wij opmaken dat de aanhangers de beweging dus langdurig trouw lijken te blijven. ${ }^{8}$

Vanaf de beginjaren van deze eeuw krijgen deze publieke activiteiten steeds meer vorm en vinden er regelmatig publieke bijeenkomsten plaats in Nederland. Toespraken die tijdens deze bijeenkomsten worden gehouden, worden anno 2020 digitaal verspreid via sociale media zoals YouTube en Facebook. Op de websites van Hizb ut-Tahrir worden naast die toespraken ook langere, Arabisch- en Nederlandstalige publicaties - boekwerken - aangeboden (waarbij de Nederlandstalige publicaties vooral vertalingen zijn uit het Arabisch). Ten minste vijf van de acht Nederlandstalige publicaties die anno 2020 op deze website worden aangeboden, zijn na 2013 herdrukt of voor het eerst gepubliceerd. ${ }^{9}$ In 2017 werd het ruim tweehonderd pagina's tellende document De Staatsinrichting van de Khilafah (inzake regeren en bestuur) door Hizb ut-Tahrir gepubliceerd. ${ }^{10}$ Het corpus van dit soort langere Nederlandstalige partijpublicaties lijkt dus met name in die jaren te zijn gegroeid.

In deze publicaties wordt uitgebreid aandacht besteed aan de manier waarop Hizb ut-Tahrir te werk gaat:

'De partij hanteert voor zijn intellectuele en politieke handelingen verschillende manieren en middelen: zoals persoonlijk contact, het verspreiden van pamfletten, het geven van persverklaringen, lessen, seminars, lezingen en

7 Binnenlandse Veiligheidsdienst 1998, p. 20, 22.

8 Waarnemingen eerste auteur.

9 Hizb ut-Tahrir Nederland, Na de Arabische Lente, de islamitische khilafah, een manifest voor verandering, 2013; Hizb ut-Tahrir, Gevaarlijke concepten, om Islam aan te vallen en te verenigen met de Westerse beschaving, 2015; Hizb ut-Tahrir - Europa, Het Goddelijk Oordeel betreffende de deelname van de moslims aan het politieke leven in het Westen, 2015; O. Pala, Niet-moslims in de Khilafah Staat, 2015; Hizb ut-Tahrir - Europa, Introductie tot Hizb ut Tahrir, 2015, beschikbaar op http:// hizb-ut-tahrir.nl/index.php/boeken.

10 Zie bijv. ook Hizb ut-Tahrir, De staatsinrichting van de Khilafah (inzake regeren en bestuur), 2017, beschikbaar op http://khilafahconferentie.nl/wp-content/uploads/2017/04/De-Staatsinrichtingvan-de-Khilafah-ONLINE.pdf. 
conferenties, het uitgeven van boeken, het houden van demonstraties en activiteiten via de sociale media en ook andere manieren die de partij geschikt acht voor zijn intellectuele en politieke handelingen. ${ }^{11}$

Dit in het partijprogramma gepresenteerde beeld van de activiteiten zien we ook terug in de wijze waarop aanhangers en de organisatie zich sinds het begin van deze eeuw manifesteren in de Nederlandse samenleving. Ze demonstreren, houden lezingen, flyeren en organiseren conferenties in verschillende Nederlandse steden. In 2004 meldden Nederlandse media dat Hizb ut-Tahrir een grote publieke bijeenkomst poogde te organiseren in het Rotterdamse stadion De Kuip. De bijeenkomst werd afgezegd omdat de eigenaar van de accommodatie alsnog weigerde de locatie te verhuren voor deze bijeenkomst. Maar Hizb ut-Tahrir gaf elders in Rotterdam een persconferentie waar ze haar standpunten uiteenzette. ${ }^{12}$ De eerste campagne waarmee Hizb ut-Tahrir landelijk nog meer de aandacht op zich wist te vestigen, vond plaats in 2007. Onder de titel 'Halt! Tegen het lasteren van Islam' organiseerde Hizb ut-Tahrir een handtekeningenactie. De organisatie riep moslims in Nederland op om zich uit te spreken tegen degenen die de islam belasteren en was een reactie op Ehsan Jami en Geert Wilders die aankondigden om islam-kritische films te zullen publiceren. ${ }^{13}$ Volgens Hizb ut-Tahrir zetten meer dan 20.000 mensen hun handtekening. ${ }^{14}$ Enkele jaren later, in 2011, organiseerde Hizb ut-Tahrir de eerste 'Khilafah Conferentie' in Amsterdam, waar honderden mensen op afkwamen. ${ }^{15}$

Dergelijke landelijk aangekondigde bijeenkomsten werden het afgelopen decennium doorgaans door enkele honderden tot ongeveer duizend geïnteresseerden met uiteenlopende achtergronden bezocht en werden regelmatig - dat wil zeggen jaarlijks - georganiseerd. Nederlandse aanhangers van Hizb ut-Tahrir reizen ook naar het buitenland om dit soort bijeenkomsten te bezoeken. Omgekeerd bezoeken aanhangers van Hizb ut-Tahrir uit andere landen Nederland, bijvoorbeeld om te spreken tijdens bijeenkomsten. ${ }^{16}$

Naast optredens tijdens deze bijeenkomsten zetten aanhangers zich ook individueel in om het gedachtegoed van de beweging uit te dragen. Ze treden op tijdens bijeenkomsten van onder andere jongerenverenigingen, studentenverenigingen en debatgroepen om hun boodschap te verspreiden. Ze nemen daarnaast ook deel

11 'Het partijprogramma van Hizb ut Tahrir - Nederland', 22 oktober 2014, p. 3, beschikbaar op www.hizb-ut-tahrir.nl/index.php/hizb-ut-tahrir.

12 'Omstreden bijeenkomst in Kuip gaat niet door', De Telegraaf 23 februari 2004, p. 3. Zie ook 'Terreurgroepering komt toch bijeen in Rotterdam', De Telegraaf 26 februari 2004, p. 7.

13 Zie bijv. 'Moslims folderen tegen "lasterwerk"', NRC Handelsblad 28 december 2007, beschikbaar op www.nrc.nl/nieuws/2007/12/28/moslims-folderen-tegen-lasterwerk-11459239-a185043.

14 https://hizb-ut-tahrir.nl/index.php/persverklaringennl/260-persbericht-voortgang-campagnehalt-tegen-het-lasteren-van-islam.

15 Waarnemingen eerste auteur. Zie ook O. Pala, 'De eerste Khilafah Conferentie van Hizb ut Tahrir Europa in Amsterdam was een groot succes', 25 juni 2011, beschikbaar op https://hizb-uttahrir.nl/index.php/persverklaringennl/244-de-eerste-khilafah-conferentie-van-hizb-ut-tahrireuropa-in-amsterdam-was-een-groot-succes. 
aan discussies op internet en aan lezingen of schrijven opiniërende stukken, soms namens Hizb ut-Tahrir en soms op persoonlijke titel.

Meerdere aanhangers van Hizb ut-Tahrir zijn bovendien betrokken bij de organisatie van media-initiatieven die als platform dienen om de ideeën van de beweging uit te dragen. Voorbeelden van dergelijke initiatieven zijn Expliciet: het magazine voor een islamitisch bewustzijn, dat in april 2000 voor het eerst verscheen, en de opvolger daarvan, De Oemma. Vanaf halverwege het eerste decennium van deze eeuw worden verklaringen van Hizb ut-Tahrir en vertaalde delen uit Arabische partijpublicaties gepubliceerd in Expliciet, dat tot ongeveer 2015 werd verspreid in Nederland en België, waarna het werd vervangen door De Oemma. Er zijn inmiddels meer dan zestig edities van deze magazines verschenen. Naast vertalingen van partijpublicaties bevatten de tijdschriften overwegend artikelen waarin uiteenlopende onderwerpen worden besproken, zoals de economische crisis, de oorlogen in Afghanistan en Irak en thema's die raken aan het (geloofs)leven van moslims, bijvoorbeeld het debat over de hoofddoek. Door De Oemma en Expliciet zijn ook uitgebreidere publicaties verspreid waarin ideeën die kenmerkend zijn voor de ideologie van Hizb ut-Tahrir uiteen worden gezet. ${ }^{17}$ Naast deze geschreven content produceert De Oemma anno 2020 ook grafisch hoogwaardige content, waaronder video's die verspreid worden via sociale media zoals Facebook. ${ }^{18}$

Hizb ut-Tahrir Nederland organiseert ten slotte naast publieke bijeenkomsten ook activiteiten met minder publiek en een meer besloten karakter. Het zijn bijeenkomsten die georganiseerd zijn om moslims - veelal jongeren en jongvolwassenen - kennis te laten maken met de ideologie van de beweging en hen ideologisch te vormen. Tijdens de grotere publieke manifestaties worden geïnteresseerden soms uitgenodigd om deel te nemen aan dit soort kleinschalige activiteiten. In kleinere kring - bijvoorbeeld in huiskamers - voeren aanhangers dan gesprekken met die geïnteresseerden en bespreken ze de actualiteit aan de hand van partijpublicaties en onderwijzen ze de ideologie. Dit soort bijeenkomsten vindt plaats in heel Nederland. Tijdens deze vormende activiteiten lijken aanhangers zich vooral te richten tot schoolgaande jongvolwassenen en jongeren. ${ }^{19}$

\section{De ideeën van Hizb ut-Tahrir}

Om te begrijpen wat Hizb ut-Tahrir en haar aanhangers in Nederland doen en zeggen, moeten we terug naar de jaren vijftig van de vorige eeuw, toen de beweging werd opgericht door Taqiuddin al-Nabhani (1909-1977). Hij is afkomstig uit een Palestijnse familie van geestelijken en islamitisch rechtsgeleerden en studeerde aan al-Azhar in Caïro. Een studie naar de ontstaansgeschiedenis en ontwikkeling van Hizb ut-Tahrir laat zien dat de manier waarop al-Nabhani keek

17 Zie bijv. De weg naar geloof, Expliciet Publicaties 1 juni 2006. Zie ook Gabar oel-Ahad vormt geen bewijs in 'Aqieda', beschikbaar op http://deoemma.nl/boeken/.

18 Zie https://nl-nl.facebook.com/OemmaNieuws. Zie ook http://deoemma.nl/.

19 Gesprekken eerste auteur met 'geïnteresseerden'. Zie bijv. ook M. Zeegers, Ik was een van hen, drie jaar undercover onder moslims, Uitgeverij Podium 2017, p. 173-182. 
naar de politieke ontwikkelingen rondom zich en naar de islam, van bepalende invloed is geweest voor de organisatie-, strategie en ideologie van de beweging. ${ }^{20}$ Het omvangrijke oeuvre van al-Nabhani bevat boeken waarin hij zijn kritiek op het kapitalisme en andere ideologieën uiteenzet, en zijn visie geeft op de islam, het kalifaat en de structuur en werkwijze van Hizb ut-Tahrir. Deze boeken worden tot op de dag van vandaag vertaald en verspreid door de beweging - ook in Nederland. ${ }^{21}$

Al-Nabhani richtte Hizb ut-Tahrir in 1953 op in Jeruzalem. De politieke ontwikkelingen in het Midden-Oosten volgden elkaar destijds in rap tempo op. De Tweede Wereldoorlog was net ten einde, de staat Israël was in 1946 uitgeroepen en in 1948 door de meeste leden van de internationale gemeenschap erkend. Tijdens de oorlog die gepaard ging met de uitroeping van de staat Israël vluchtten veel Palestijnen naar de omliggende Arabische landen. Het socialisme won terrein in de Arabische wereld en dat gold ook voor daaraan gelieerde politieke bewegingen; de Ba'ath-partij werd bijvoorbeeld invloedrijk in Syrië en Irak.

Al-Nabhani meende dat in het postkoloniale tijdperk sprake was van een sociale en politieke teloorgang in de samenleving. Om deze teloorgang te stoppen moest de islam weer de levende leidraad van moslims worden en dat kon in zijn ogen alleen door het vestigen van een islamitische staat - een kalifaat. Het kalifaat als staatsvorm kent een lange geschiedenis in de soennitische islam, en werd in de negentiende eeuw nog belichaamd door het Ottomaanse Rijk. In 1923 echter verving de Turkse leider Kemal Attaturk het Ottomaanse Rijk door de Turkse Republiek en schafte daarmee tevens formeel het kalifaat af.

In zijn wens tot de heroprichting van het kalifaat richtte al-Nabhani daarom Hizb ut-Tahrir op, een beweging die moslims moest overtuigen van dit idee en moest toewerken naar een machtsovername zodat een kalifaat kon worden gevestigd. Hiertoe ontwierp hij een celstructuur van activisten. Allereerst moesten aanhangers besloten, lokaal georganiseerde kaders in de vorm van leskringen opbouwen die onderdeel gingen uitmaken van een strikt geleide top-down bestuurde politieke organisatie. Binnen deze leskringen werden nieuwelingen onderwezen in de ideologie. $\mathrm{Na}$ hun initiatieperiode zwoeren ze trouw aan de leider ('emir') van Hizb ut-Tahrir en werden ze geacht zich te confirmeren aan de ideologische standpunten en zich gehoorzaam op te stellen aan het leiderschap. Deze geïnitieerde aanhangers traden vervolgens in contact met lokale moslimgemeenschappen waar zij zelf deel van uitmaakten, met als doel hen ertoe te bewegen zich af te keren van niet-islamitische ideologieën en van de regimes en elites die deze ideologieën hadden omarmd. Volgens al-Nabhani moest er dus allereerst een mentaliteitsverandering onder de massa's tot stand worden gebracht. Als de moslimbevolking - waaronder ook machtige groepen zoals intellectuelen en het leger afstand zouden nemen van de ideeën die ten grondslag liggen aan het politieke systeem dat de elite in stand houdt, zou een politieke revolutie praktisch vanzelf

20 Taji-Farouki 1996.

21 Zie bijv. www.hizb-ut-tahrir.org/index.php/EN/books/. Zie ook https://hizb-ut-tahrir.nl/ index.php/boeken. 
volgen, zo was zijn gedachte. Hizb ut-Tahrir moest in dit proces dienen als de intellectuele voorhoede die zich onder de moslimbevolking moest mengen om deze te onderwijzen, te overtuigen en op te komen voor de belangen van moslims. Deze werkwijze lag volgens al-Nabhani in lijn met de wijze waarop de Profeet Mohammed de islam verspreidde, maar vertoont ook sterke gelijkenissen met vroeg-leninistische ideeën over de rol die een politieke partij moet vervullen. ${ }^{22}$

Al-Nabhani hechtte zeer aan de juiste structuur, werkwijze en strategie van de organisatie die hij opbouwde en was kritisch en afkeurend naar andere organisaties die samenlevingen willen hervormen naar het islamitische ideaal, zoals de Moslimbroederschap. Hij bekritiseerde deze organisaties omdat ze in zijn ogen niet op de juiste manier te werk gingen, gebaseerd waren op verkeerde ideeën of verkeerde doelen nastreefden. ${ }^{23}$ Later richtte dergelijke kritiek zich ook op salafisten. Salafisten waren in de ogen van Hizb ut-Tahrir te veel georiënteerd op theologische hervorming in plaats van politieke hervorming, en zouden te weinig kritisch zijn richting heersende regimes en daarmee de politieke status quo in stand houden, wat hen op de beschuldiging van collaboratie kwam te staan. ${ }^{24}$ Dit soort kritiek op andere moslimorganisaties zien we ook terug in de Nederlandse context. De woordvoerder ('lidvertegenwoordiger') van Hizb ut-Tahrir Nederland, Okay Pala, uit op sociale media soms felle kritiek op islamitische organisaties die overheidsbeleid steunen en gebruikt daarbij termen als 'verraders'. ${ }^{25}$

\subsection{Wat is het probleem?}

De sociale teloorgang die al-Nabhani om zich heen zag, weet hij aan vreemde, niet-islamitische invloeden van ideologieën zoals het kapitalisme en socialisme die door koloniale machtshebbers waren geïntroduceerd en volgens hem steeds meer grip kregen op moslims. Hij bestempelde deze ideologieën categorisch als ongeloof, en de regimes die deze ideologieën omarmden als ongelovig. De islamitische wereld was in zijn ogen niet langer islamitisch, maar verworden tot een 'domein van ongeloof. Het construct van natiestaten, internationale verdragen en conventies beschouwde hij als een samenzwering tegen moslims om hen te vervreemden van de islam. ${ }^{26}$

Al-Nabhani uitte in zijn werk op verschillende manieren kritiek op ideologieën zoals kapitalisme en socialisme, die aan de basis liggen van het handelen van koloniale wereldmachten. Deze gaan volgens hem bijvoorbeeld voorbij aan de instinctieve behoefte van de mens om het goddelijke te aanbidden, en daarom druisen

Zie bijv. Taji-Farouki 1996, p. 76-105 en p. 114-152. Zie ook N. Hanif, The securitisation of Hizb ut tahrir, a comparative case study (diss. University of London), 2014, p. 69-88, beschikbaar op https://pure.royalholloway.ac.uk/portal/en/publications/the-securitisation-of-hizb-uttahrir(ed707e9d-34a4-4b8f-9362-c8c0740cb722).html.

23 Zie bijv. Taji-Farouki 1996, p. 76-85.

24 Zie bijv. Hanif 2014, p. 61-62.

25 Zie https://twitter.com/Okay_Pala/status/1320961132862054400.

26 Taji-Farouki 1996, p. 37-45, 71-75. Zie ook S. Taji-Farouki, 'Islamists and the threat of Jihad: Hizb al-Tahrir and al-Muhajiroun on Israel and the Jews', Middle Eastern Studies 2000/4, p. 22-24. 
het kapitalisme en socialisme in tegen de menselijke aard - 'natuur'. Het kapitalisme wakkert hebzucht aan en al-Nabhani beschouwde kolonialisme als een uitwas van die hebzucht. ${ }^{27}$ Deze redeneerlijn is terug te vinden in de Nederlandstalige partijpublicaties van Hizb ut-Tahrir, zoals Na de Arabische Lente, dat in 2013 werd gepubliceerd:

'Het westerse systeem garandeert dat het niet uitmaakt hoe goed of altruïstisch de mensen ook mogen zijn, het systeem dwingt besluitvorming af die zelfzuchtig is, op korte termijn gericht is, en individuele belangen bevoordelen ten opzichte van belangen van de samenleving en de natie. ${ }^{28}$

Deze redeneerwijze is ook in de jaren na 2000 al terug te vinden in Expliciet, waar uiteenlopende thema's worden besproken, zoals armoede, maar ook de oorlogen in Afghanistan (2001) en Irak (2003) en de economische crisis van 2008. Deze crisis en oorlogen worden uitgelegd als uitwassen van het kapitalisme en het falen van overheden die hun beleid op het kapitalisme baseren. De auteurs onderbouwen hun analyses regelmatig met het door al-Nabhani gebruikte argument dat kapitalisme indruist tegen de menselijke natuur. ${ }^{29}$ Hizb ut-Tahrir beschouwt het falend politiek leiderschap en overheidsbeleid dus als uitvloeisel van falende ideologieën, met maatschappelijk verval tot gevolg.

Marginalisering van moslimgemeenschappen is volgens Hizb ut-Tahrir inherent aan dit verval. Wanneer het aankomt op kwesties die raken aan het welzijn van moslimgemeenschappen of de islam, uit Hizb ut-Tahrir in Nederland felle kritiek op de overheid. Het meest sprekende voorbeeld is de kritiek van de organisatie op het antiterrorismebeleid in Nederland en meer algemeen het antiterrorismebeleid van westerse overheden - the war on terror. Antiterrorismebeleid in Nederland maakt volgens Hizb ut-Tahrir van iedere moslim een terrorist, vervreemdt moslims van de islam en werd tijdens een campagne in 2014 uitgelegd als 'antiislambeleid'. ${ }^{30}$ In een vertaalde publicatie wordt het antiterrorismebeleid bestempeld als een strategisch wapen dat wordt gebruikt door de Verenigde Staten om hun grip op de wereld te versterken:

'Sinds dat Amerika Islam heeft geïdentificeerd als haar grootste vijand na de val van het communisme, worden de Islamitische landen nu beschouwd als

28 Hizb ut-Tahrir Nederland, Na de Arabische Lente. De islamitische khilafah, een manifest voor verandering, 2013, p. 8.

29 Zie bijv. H. Thea, 'Commentaar: De islam als alternatief', Expliciet 2000/2, p. 10-11. Zie ook 'Amerika \& armoede \& de democratische conventie', Expliciet 2001/7, p. 17-18; 'Een blik op de wereld, de ware motieven achter de dreigende oorlog op Irak', Expliciet 2002/11, p. 15-17.

30 Zie bijv. www.hizb-ut-tahrir.nl/index.php/pamfletten-hizb-ut-tahrir-europa/374-samen-tegenanti-islambeleid. Zie ook 'Gevaarlijke concepten, om Islam aan te vallen en te verenigen met de Westerse beschaving', 2015, p. 5-9. 
strategische gebieden waarin ze de antiterrorisme wetgeving zullen gebruiken om hun invloed te vergroten en ze onder controle te houden.' ${ }^{31}$

In allerlei Nederlandstalige publicaties bekritiseren aanhangers van Hizb ut-Tahrir het dominante discours met betrekking tot terrorisme; de juistheid van berichtgeving over jihadistische aanslagen wordt in twijfel getrokken, evenals de objectiviteit van media en de aard en oorzaak van jihadistisch terrorisme. ${ }^{32}$ Terrorisme wordt dus niet beschouwd als objectief gegeven, maar als een westerse constructie die een politiek doel dient, namelijk: machtsbehoud en verhulling van problemen. Zoals een Nederlandse aanhanger stelt:

'De strijd tegen terreur is een rookgordijn dat wordt opgetrokken om werkelijke problemen zoals stijgende zelfmoordcijfers, doodslag, huiselijk geweld, drugsgebruik en alcohol gerelateerde vraagstukken te verdoezelen. Echter neemt dat niet weg dat wij de waarheid zullen blijven spreken, de hypocrisie zullen blijven aankaarten.'33

Al-Nabhani betoogde dat moslims zich moesten afkeren van niet-islamitische ideologieën - ongeloof - en de daaruit voortvloeiende ideeën en politieke systemen zoals democratie. Indachtig dit betoog ontraadt Hizb ut-Tahrir moslims in het Westen om deel te nemen aan de democratie: politieke partijvorming, het parlement, de regering en verkiezingen. ${ }^{34}$ Rond verkiezingscampagnes organiseerde Hizb ut-Tahrir daarom flyeracties bij moskeeën en voerde online campagnes waarin het moslims werd ontraden om deel te nemen aan verkiezingen. ${ }^{35}$

Hizb ut-Tahrir waarschuwt moslims ook voor de 'interreligieuze dialoog'. De organisatie beschouwt een dialoog namelijk als een middel om ideeën met elkaar in overeenstemming te brengen en daarin schuilt een gevaar: '(...) het is een dialoog gepresenteerd door de vijanden van Islam met het doel Islam, de Islamitische beschaving en de Islamitische oemma te vernietigen. ${ }^{36}$ Dat neemt niet weg dat aanhangers van Hizb ut-Tahrir actief deelnemen aan gesprekken en discussies, zij het echter niet met als doel om ideeën met elkaar in overeenstemming te brengen, maar eerder om hun standpunten uit te dragen en te verdedigen. ${ }^{37}$

31 Hizb ut-Tahrir, Gevaarlijke concepten, om Islam aan te vallen en te verenigen met de Westerse beschaving', 2015, p. 7.

32 Zie bijv. 'Redactioneel' Expliciet 2001/7, p. 1. Zie bijv. http://deoemma.nl/persverklaring-vanhizb-ut-tahrir-nederland-aangaande-de-recente-gebeurtenissen-in-frankrijk/; http://deoemma. $\mathrm{nl}$ /staatsterrorisme-zorgt-voor-dood-en-verderf-op-aarde/.

33 http://deoemma.nl/staatsterrorisme-zorgt-voor-dood-en-verderf-op-aarde/.

34 Het Goddelijk Oordeel betreffende de deelname van de moslims aan het politieke leven in het Westen, 2015.

35 Zie bijv. 'Campagne Hizb ut-Tahrir tegen verkiezingen', Algemeen Nederlands Persbureau 2 juni 2010. Zie ook www.trouw.nl/nieuws/oproep-moslims-om-niet-te-stemmen b4a1979c/.

36 Hizb ut-Tahrir, 'Gevaarlijke concepten, om Islam aan te vallen en te verenigen met de Westerse beschaving', 2015, p. 18.

37 Zie bijv. https://decorrespondent.nl/1724/dit-had-ik-tegen-jeroen-pauw-willen-zeggen-over-hetanti-jihadbeleid-van-minister-opstelten/99467374732-24708bf4. 


\subsection{Wat is de oplossing?}

Tegenover alle misstanden stelde al-Nabhani de islam, volgens hem een ideologie die rationeel van karakter is omdat de juistheid ervan kon worden vastgesteld door middel van zintuigelijke waarneming en logische redeneringen (syllogismen), en verankerd lag in islamitische bronteksten die in zijn ogen onfeilbaar waren: de Koran en de betrouwbare - muttawatir - Hadith. ${ }^{38}$ Al-Nabhani was ervan overtuigd dat de islam superieur is ten opzichte van alle andere ideologieën, omdat deze is gebaseerd op ultieme waarheid die te vinden is door juiste waarneming, redeneerwijzen en raadpleging van islamitische bronnen.

Vanaf het eerste decennium van deze eeuw richt Hizb ut-Tahrir zich in Nederland op het uitdragen van de beginselen van deze islamitische doctrine zoals geformuleerd door al-Nabhani. In populariserende video's, artikelen, campagnes en geschreven publicaties wordt de islam als rationele ideologie gepresenteerd. ${ }^{39}$ Daarnaast zijn er ook Nederlandstalige publicaties te vinden waarin tot in detail wordt ingegaan op de theologische stellingname van al-Nabhani met betrekking tot de islam en waarin deze worden verdedigd. ${ }^{40}$

Naast een eigen visie op de geloofsleer werkte al-Nabhani ook een eigen visie uit op de islamitische wet, die als levende leidraad moest dienen in het door hem beoogde kalifaat. Hij pleitte voor eigenstandige interpretatie - ijtihad -, maar stelde hier wel strikte voorwaarden aan zodat de rede ondergeschikt was ten opzichte van de Openbaring. ${ }^{41}$ Al-Nabhani had in de beginjaren vijftig van de vorige eeuw al een grondwet opgesteld voor het beoogde kalifaat. Een tientallen pagina's tellend document waarin niet alleen gedetailleerd wordt ingegaan op de staatsinrichting met betrekking tot het sociaal stelsel, buitenlandse betrekkingen en de economie, maar ook op aspecten van het sociale leven waar de islamitische wet betrekking op heeft, zoals de rol van man en vrouw en de scheiding van seksen. Dit kalifaat presenteert hij als een alternatief voor democratische natiestaten. De soevereiniteit behoort in dit kalifaat toe aan God en niet aan het volk. Die goddelijke soevereiniteit trachtte al-Nabhani bijvoorbeeld te waarborgen door de (moslim)bevolking uit te sluiten van het proces van wetgeving. Het uitvaardigen van wetten was in zijn optiek een voorrecht van de kalief die door het volk was aangewezen. ${ }^{42}$

Ook in Nederland wordt dit kalifaat gepresenteerd als alternatief politiek systeem. In lezingen van aanhangers en schriftelijke uitingen van Hizb ut-Tahrir wordt voortdurend benadrukt dat het kalifaat de enige wezenlijke politieke oplossing is. Niet voor niets draagt de vrijwel jaarlijks terugkerende landelijke conferentie de Arabischtalige naam van het kalifaat: Khilafah conferentie. De afgelopen

39 Zie bijv. 'De weg naar geloof', Expliciet Publicaties 1 juni 2006. Zie ook de documentaire 'De weg tot geloof, HizbutTahrirnl 6 januari 2006, beschikbaar op www.youtube.com/watch?v=nxKMZK_s-c; zie ook www.youtube.com/watch?v=o53cp5ti0Lc.

40 Zie bijv. Gabar oel-Ahad vormt geen bewijs in 'Aqieda', beschikbaar op http://deoemma.nl/boeken/.

41 Taji-Farouki 1996, p. 55-63.

42 Zie bijv. Taji-Farouki 1996, p. 63-70 en 193-218. 
jaren zijn de details van deze geïdealiseerde staat regelmatig uiteengezet in verschillende Nederlandstalige publicaties die zijn uitgegeven door de organisatie. ${ }^{43}$

\section{Wel actief, geen macht}

In de eerste decennia na de oprichting van Hizb ut-Tahrir groeide de populariteit van de beweging in gebieden als de Westelijke Jordaanoever aanvankelijk snel, maar het doel - vestiging van een kalifaat - is, ondanks enkele couppogingen in de jaren zestig en zeventig die aan de beweging worden toegeschreven, nooit verwezenlijkt. Ook de toenadering van het leiderschap van Hizb ut-Tahrir tot Khomeini, de leider van de Iraanse revolutie in de jaren zeventig, bleef vruchteloos, ${ }^{44}$ en de Arabische Lente vormde voor Hizb ut-Tahrir eveneens niet het juiste momentum. Bijna zeventig jaar na haar oprichting is de beweging in bijna alle Arabische landen verboden. Dit neemt niet weg dat algemeen wordt aangenomen dat de beweging momenteel actief is in ruim veertig landen wereldwijd. ${ }^{45}$ Schattingen over het aantal aanhangers in westerse landen zoals Denemarken en het Verenigd Koninkrijk lopen uiteen van respectievelijk enkele honderden tot ruim duizend. ${ }^{46}$

Belangrijk is om hier te benadrukken dat in de westerse landen waar Hizb ut-Tahrir actief is, niet wordt gestreefd naar omverwerping van regeringen. De (her)oprichting van het kalifaat moet volgens al-Nabhani namelijk plaatsvinden in Arabischtalige landen, omdat de moslimbevolking in deze landen vertrouwd is met de taal van de Koran en andere islamitische bronnen. Dit was volgens al-Nabhani van groot belang om moslims in deze landen ervan te kunnen overtuigen dat de islam de oplossing voor hun problemen is. In deze gebieden - goedbeschouwd het Arabischtalige Midden-Oosten - richt Hizb ut-Tahrir zich actief op overname van de macht. ${ }^{47}$

In lijn met dit standpunt wordt in het partijprogramma van Hizb ut-Tahrir Nederland gesteld dat de beweging er in beginsel niet naar streeft aan de macht te komen in Nederland. In plaats van te streven naar een kalifaat zegt Hizb ut-Tahrir zich in Nederland alleen te richten op het uitdragen van de eigen "islamitische boodschap' - naar zowel moslims als niet-moslims. Daarmee streeft de beweging

43 Zie bijv. Na de Arabische Lente, de islamitische khilafah, een manifest voor verandering, 2013. Zie ook De staatsinrichting van de Khilafah (inzake regeren en bestuur), 2017.

44 Taji-Farouki 1996, p. 27-28, 31. Zie ook Hanif 2014, p. 122-131.

45 Zie. bijv. E. Orofino, 'Framing, new social identity and long-term loyalty. Hizb ut-Tahrir's impact on its members', Social Movements Studies 2020, p. 2, beschikbaar op www.tandfonline.com/doi/ full/10.1080/14742837.2020.1722629. Zie ook Hanif 2014, p. 51.

46 Zie bijv. K. Sinclair, Caliphate as Homeland: Hizb ut-Tahrir in Denmark and Britain (diss. University of Southern Denmark), 2010, p. 77 beschikbaar op https://citeseerx.ist.psu.edu/viewdoc/ download?doi=10.1.1.464.2997\&rep=rep1\&type=pdf.

47 Zie Taji-Farouki 1996, p. 102-105. Zie ook Hanif 2014, p. 90-142. 
volgens eigen zeggen naar het behoud van 'de islamitische identiteit van moslims' en de behartiging van 'de belangen van de islamitische gemeenschap'. ${ }^{48}$

\section{$5 \quad$ Blijft het altijd bij woorden?}

Anders dan jihadistische organisaties zoals Al Qaida die ook streven naar een kalifaat, beschouwde al-Nabhani de gewapende strijd niet als een legitiem middel om het kalifaat te vestigen. Moslims moesten zich volgens al-Nabhani in beginsel op geweldloze wijze inzetten voor terugkeer van het kalifaat, waarna de leider van deze staat - de kalief - de jihad tegen ongelovigen kan sanctioneren. Met ongelovigen werden in dit geval overigens niet de niet-moslims bedoeld, maar de moslims die niet volgens de juiste islamitische beginselen leefden en iedereen - moslim of niet-moslim - die zich tegen het kalifaat verzette. Dit standpunt maakt het kalifaat in praktijk een conditio sine qua non voor de jihad. Op dit punt bleef alNabhani dus dichter bij de opvattingen van klassieke islamitische geleerden dan zijn tijdgenoot Sayyid Qutb, die opriep tot onmiddellijke strijd tegen heersende regimes. ${ }^{49}$ Hizb ut-Tahrir wijkt ook in Nederland niet af van dit idee: geweld als middel om politieke doelen te bereiken wordt principieel afgekeurd. ${ }^{50}$

Het is ook niet verrassend dat de huidige leider (emir) van Hizb ut-Tahrir, Ata bin Khalil Abu al-Rashta, het door de jihadistische organisatie uitgeroepen kalifaat niet erkende en deze claim al in 2014 afdeed als betekenisloos - 'retoriek'. ${ }^{51}$ Hizb ut-Tahrir heeft zich in verschillende Nederlandstalige publicaties ook principieel uitgesproken tegen terroristische aanslagen in het Westen die gepleegd worden in naam van de islam waarbij burgers het doelwit zijn. Het standpunt is dat dergelijk geweld verboden is volgens de islam. ${ }^{52}$

Dit neemt echter niet weg dat al-Nabhani de gewapende strijd van moslims tegen degenen die worden beschouwd als niet-islamitische bezetters van islamitische gebieden, in principe als legitiem beschouwde. ${ }^{53}$ Moslims in deze gebieden hebben volgens Hizb ut-Tahrir de plicht om zichzelf te verdedigen tegen die bezetters, zo is het principiële standpunt. ${ }^{54}$ Ook in een Nederlandstalige publicatie van Hizb ut-Tahrir is een passage te vinden waaruit valt op te maken dat geweld tegen niet-islamitische bezetters van islamitisch grondgebied in beginsel wordt gerechtvaardigd:

48 'Het partijprogramma van Hizb ut Tahrir - Nederland', beschikbaar op https://hizb-ut-tahrir.nl/ media/pdf/Partij\%20Programma\%20Hizb\%20ut\%20Tahrir\%20Nederland.pdf.

49 Zie bijv. Taji-Farouki 1996, p. 109-110. Zie ook Taji-Farouki 2004, p. 27-30.

50 Zie bijv. 'Het partijprogramma van Hizb ut Tahrir - Nederland', p. 3, beschikbaar op https:// hizb-ut-tahrir.nl/media/pdf/Partij\%20Programma\%20Hizb\%20ut\%20Tahrir\%20Nederland.pdf.

51 Zie bijv. http://hizb-ut-tahrir.nl/index.php/politiek/355-v-a-aangaande-de-khilafah-verklaringvan-isis.

52 Zie bijv. T. Broer, “Als je moslims bent, kun je geen democraat zijn”, interview Okay Pala', Vrij Nederland 24 juli 2004; 'Redactioneel', Expliciet 2001/7, p. 1; 'Belofte', Expliciet 2004/16. p. 20-22.

53 Zie bijv. Taji-Farouki 1996, p. 109-110.

54 Zie bijv. Taji-Farouki 2004, p. 27-30, 39-40; H. Ahmed \& H. Stuart, Hizb ut-Tahrir, ideology and strategy, Centre for Social Cohesion 2009, quote op p. 29. 
'Het feit dat de Partij geen fysieke handelingen gebruikt om zichzelf te verdedigen, of als wapen tegen de heersers, is niet relevant betreffende het onderwerp jihad, want jihad dient te geschieden tot de Dag des Oordeels. Dus wanneer ongelovige vijanden een islamitisch land aanvallen wordt het een verplichting op de moslims deze vijand te verwijderen. De leden van Hizb utTahrir in dat land behoren tot de moslims en het is verplicht voor hen, evenzo als voor andere moslims, in hun identiteit als moslim de vijand te bevechten en te verwijderen. Wanneer ook een moslim Amir (leider) jihad uitroept om het woord van Allah (swt) te verspreiden en de mensen derhalve mobiliseert, zullen de leden van Hizb ut-Tahrir antwoorden naar hun identiteit als moslim in het land waar de oproep tot de wapenen gedaan is. ${ }^{55}$

Hizb ut-Tahrir zegt dus geen gewelddadige werkwijze te hanteren om politieke doelen te bereiken, maar stelt tegelijkertijd dat moslims zich bijvoorbeeld moeten kunnen verdedigen. Bijvoorbeeld tegen Amerikaanse troepen ten tijde van de oorlog in Irak (2003). Op de vraag of hij 'de strijd tegen de Amerikanen in Irak' steunt, antwoordde de Nederlandse woordvoerder Okay Pala van Hizb ut-Tahrir tijdens een interview in 2004:

'Niet als lid van Hizb ut-Tahrir, want wij richten ons niet op gewapende strijd, maar wel als moslim. 56

Ook Israël wordt door Hizb ut-Tahrir beschouwd als niet-islamitische bezetter van gebied dat in de ogen van de beweging van oudsher toebehoort aan moslims. Hizb ut-Tahrir roept moslims daarom op om Israël te bestrijden, zij het op indirecte wijze: Hizb ut-Tahrir roept het leger, de moslimbevolking en regimes van Arabische landen op om eerst te streven naar een kalifaat, zodat de kalief de gewapende strijd tegen Israël kan sanctioneren. Daarnaast zijn er voorbeelden te vinden van aanhangers van Hizb ut-Tahrir die gewelddaden tegen Israëlische doelen vergoelijkten, waaronder ook Israëlische staatsburgers, die door de beweging categorisch worden beschouwd als militaire vijand. ${ }^{57}$ Dat Hizb ut-Tahrir geweld als middel afwijst om het ideaal van het kalifaat te verwezenlijken, betekent in praktijk dus niet dat aanhangers van Hizb ut-Tahrir zich onthouden van uitspraken over de jihad of uitspraken waarin bepaalde vormen van geweld worden vergoelijkt of worden gerechtvaardigd.

Vanwege de standpunten ten aanzien van Israël zijn de activiteiten van de beweging sinds 2003 in Duitsland verboden. Het Duitse ministerie van Binnenlandse Zaken oordeelde dat in pamfletten, publicaties en in de Duitse versie van Expliciet werd opgeroepen tot vernietiging van de staat Israël en het doden van Joden. 
Hizb ut-Tahrir vocht dit verbod aan bij het Europees Hof voor de Rechten van de Mens, dat de Duitse staat echter in het gelijk stelde. ${ }^{58}$

\section{Guilty by association?}

Met name in de jaren na de aanslagen van 9/11 in 2001 richtten Angelsaksische denktanks zich op de vraag over de relatie van de beweging tot de gewapende strijd. Er wordt in de publicaties van deze denktanks gewezen op (vermeende) aanhangers die zich afsplitsten van de organisatie en betrokken raakten bij terroristische activiteiten en op contacten tussen jihadisten en Hizb ut-Tahrir. ${ }^{59}$ In een rapport van The Nixon Center wordt zelfs gesteld dat Hizb ut-Tahrir moslims ideologisch ontvankelijk maakt voor de gewapende strijd en zodoende onderdeel uitmaakt van een 'lopende band' die naar terrorisme leidt. ${ }^{60}$ De inmiddels verboden Britse organisatie al-Muhajiroun wordt hierbij vaak als voorbeeld aangehaald, een organisatie die als afsplitsing van Hizb ut-Tahrir kan worden beschouwd en werd geleid door Omar Bakri Mohammed. Hij was een vooraanstaand aanhanger van Hizb ut-Tahrir in het Verenigd Koninkrijk. ${ }^{61}$

Ook in Nederland zijn er voorbeelden te vinden waaruit blijkt dat aanhangers contact hebben met jihadistisch georiënteerde personen en dat jihadisten geïnteresseerd zijn in de ideeën van de beweging. ${ }^{62}$ Onduidelijk is echter welke invloed deze onderlinge contacten hebben op betrokkenen. Relevant is hier te benadrukken dat aanhangers van Hizb ut-Tahrir trouw lijken te zijn aan de 'partij' en haar ideologie en dat woordvoerder Okay Pala in dat kader stelt dat de organisatie binnen de kaders van de wet wil opereren. De AIVD noemde de organisatie voor het laatst in het jaarverslag van 2011 en concludeerde toen dat de dreiging die uitgaat van deze beweging thans 'beperkt' is. ${ }^{63}$ In de daaropvolgende jaren heeft de AIVD blijkbaar geen aanleiding gezien om de beweging nog te vermelden. In 2014 het Openbaar Ministerie geen aanknopingspunten voor strafrechtelijke vervolging van Hizb ut-Tahrir. ${ }^{64}$

58 Zie bijv. 'Hizb ut-Tahrir in Duitsland verboden', Trouw 16 januari 2003. Zie ook EHRM 12 juni 2012, 31098/08 (Hizb ut Tahrir e.a./Duitsland), beschikbaar op https://hudoc.echr.coe.int/engpress\#\{\%22itemid\%22:[\%22001-111532\%22]\}.

59 Zie bijv. M. Whine, Is Hizb ut-Tahrir Changing Strategy or Tactics?, Hudson Institute, p. 5-7, beschikbaar op https://cst.org.uk/data/file/a/9/EurasianPaper_Aug42006.pdf; Z. Baran, Hizb utTahrir, Islam's Political Insurgency, The Nixon Center 2004, p. 53.

60 Baran 2004, p. 11.

61 Zie bijv. Z. Raymond, Al Muhajiroun and Islam4UK: The group behind the ban, The International Centre for the Study of Radicalisation and Political Violence 2010.

62 Zie bijv. H. Bahara, 'Enkeltje Den Haag-Syrië', De Groene Amsterdammer 13 juni 2013, beschikbaar op www.groene.nl/artikel/enkeltje-den-haag-syrie; E. Bakker \& P. Grol, Motives and Considerations of Potential Foreign Fighters from the Netherlands, International Center for Counter Terrorism 2015. p. 3-5, beschikbaar op https://icct.nl/wp-content/uploads/2015/07/ICCTBakker-Grol-Motives-and-Considerations-of-Potential-Foreign-Fighters-from-the-NetherlandsJuly2015.pdf; Zeegers 2017, p. 173-182.

63 AIVD, Jaarverslag 2011, p. 15.

64 Zie bijv. Kamerstukken II 2014/15, 29754, nr. 226, p. 13-14. 


\section{Conclusie}

Hizb ut-Tahrir is de afgelopen twee decennia zichtbaarder geworden in de Nederlandse samenleving. Enkele tientallen aanhangers dragen de boodschap van de beweging fanatiek uit en staan in contact met aanhangers van Hizb ut-Tahrir in de rest van de wereld. In de manier waarop deze activisten te werk gaan laten zij zich leiden door de ideeën van de grondlegger van de beweging, Taqiuddin al-Nabhani. Hij werkte in de jaren vijftig van de vorige eeuw zijn ideeën uit ten aanzien van de problemen die hij zag in de wereld, hoe hij deze wilde oplossen en welke rol de door hem gestichte beweging Hizb ut-Tahrir daarbij moest spelen. Aanhangers van Hizb ut-Tahrir houden tot op de dag van vandaag vast aan deze ideeën en daarmee lijkt de koers van de organisatie en van haar aanhangers ook in Nederland onveranderlijk te zijn. Dit beeld komt overeen met het beeld dat naar voren komt in andere studies naar Hizb ut-Tahrir wereldwijd. ${ }^{65}$ Dit beeld in ogenschouw nemende is er een aantal nuanceringen te plaatsen bij heersende opvattingen over de organisatie, bijvoorbeeld het idee dat Hizb ut-Tahrir gewelddadig is.

Hizb ut-Tahrir heeft een eigen kijk op de legitimiteit van geweld waar principieel aan wordt vastgehouden. Geweld als middel om het kalifaat te vestigen werd door al-Nabhani en wordt door Hizb ut-Tahrir principieel en consequent afgewezen zonder kalifaat geen jihad. Ook terroristische gewelddaden in het Westen worden consequent veroordeeld. Dat wil niet zeggen dat Hizb ut-Tahrir alle vormen van geweld tegen vermeende bezetters van islamitisch grondgebied afkeurt. Echter, aanhangers in Nederland lijken een manier te hebben gevonden om op dit punt stelling te nemen zonder daarbij buiten de in Nederland geldende wettelijke kaders te treden. Aanhangers bewegen dus niet richting het jihadisme of terrorisme, maar lijken juist strikt vast te houden aan aloude principes die de beweging kenmerken, waaronder het idee dat de gewapende strijd niet als middel kan worden ingezet om de politieke doelen van de beweging te verwezenlijken. Daarmee nuanceert dit beeld ook het idee dat Hizb ut-Tahrir een lopende band richting terrorisme vormt. Dat neem niet weg dat er ook in Nederland een zekere wisselwerking bestaat tussen aanhangers van Hizb ut-Tahrir en jihadistische netwerken. Mede door de informele en tot op zekere hoogte gesloten aard van deze netwerken is nog maar weinig bekend over het effect daarvan op betrokkenen.

Ondanks dat aanhangers in beginsel geweldloos handelen, volhardt men consequent in bepaalde ideeën waarvan zeker gesteld kan worden dat ze indruisen tegen gangbare beginselen en principes van democratie en burgerschap. De boodschap van de organisatie dat moslims zich niet moeten inlaten met democratische processen in Nederland, staat haaks op de ideeën die algemeen aanvaard zijn in Nederland. Dat is in Nederland echter nog geen reden om de organisatie te verbieden, maar roept wel voortdurend de vraag op hoever een organisatie mag gaan in het afwijzen van democratie en de grondbeginselen van democratie. De vraag

65 Zie bijv. J. Høigilt, 'Prophets in their own country? Hizb al-Tahrir in the Palestinian context', Politics, Religion and Ideology 2014/4, p. 504-520; Orofino 2020; K. Sinclair, Caliphate as Homeland: Hizb ut-Tahrir in Denmark and Britain, 2010. 
Peter Grol \& Daan Weggemans

hoe deze ideeën en activiteiten van Hizb ut-Tahrir zich verhouden tot de Nederlandse samenleving zal in een volgend artikel aan bod komen. 